\title{
ANALISIS KINERJA PERUSAHAAN KONSTRUKSI DI KABUPATEN SORONG
}

\author{
Serly Marlina \\ Program Studi Teknik Sipil Universitas Muhammadiyah Sorong \\ Jalan Pendidikan No 27 Kota Sorong, Propinsi Papua Barat \\ Email : serlymarlina723@gmail.com
}

\begin{abstract}
ABSTRAK
Dalam perkembangan dunia konstruksi khususnya di Kabupaten Sorong maka peran perusahaan sangat penting dalam menunjang kesuksesan pembangunan dimana pada kenyataannya pembangunan merupakan perioritas utama masyarakat dalam menghadapi era globalisasi. Dalam dunia konstruksi dikenal dua jenis perusahaan yaitu konsultan dan kontraktor. Perusahaan Konstruksi harus mempunyai Kinerja yang baik. Kinerja suatu perusahaan dapat dijadikan sebagai suatu tolok ukur dari kemampuan suatu organisasi atau perusahaan dalam mencapai tujuannya. Pengukuran kinerja merupakan salah satu faktor yang sangat penting bagi organisasi atau perusahaan, karena pengukuran kinerja merupakan proses mengukur sejauh mana suatu perusahaan melakukan pekerjaan untuk mencapai tujuannya. Tujuan penelitian ini yaitu untuk menganalisis kinerja perusahaan konstruksi (kontraktor) dalam lingkup Dinas Pekerjaan Umum Kabupaten Sorong dan untuk menganalisis faktor apa saja yang paling mempengaruhi kinerja perusahaan konstruksi (kontraktor) dalam menjalankan pekerjaan- pekerjaan yang ada dalam lingkup Dinas Pekerjaan Umum Kabupaten Sorong. Penelitian ini dilakukan dengan metode penelitian deskriptif. Pengumpulan data dilakukan dengan kuisioner dan wawancara. Studi pustaka dilakukan dengan pencarian literature melalui jurnal, penelitian terdahulu, internet dan buku mengenai teori-teori yang berhubungan dengan permasalahan yang dikaji.
\end{abstract}

Kata Kunci : analisis kinerja; perusahaan konstruksi ; kabupaten sorong 


\section{PENDAHULUAN}

\section{Latar Belakang}

Dinas Pekerjaan Umum Kabupaten Sorong merupakan salah satu instasi pemerintah yang bertugas sebagai penyelenggara urusan pemerintah bidang pekerjaan umum, pembangunan infrastruktur dan perumahan untuk daerah Kabupaten Sorong, Papua Barat. Terkait dengan wewenang tersebut, maka melalui kantor ini beberapa surat perizinan diproses. Beberapa surat tersebut seperti izin Pemanfaatan Ruang (IPR) dan izin Mendirikan Bangunan (IMB). Melalui kedinasan ini pula urusan pembebasan lahan proyek infrastruktur pemerintah dilakukan. Undang-Undang Republik Indonesia No. 2 tahun 2017, menyatakan bahwa Jasa Konstruksi adalah layanan jasa konsultansi konstruksi dan/atau pekerjaan konstruksi. Dalam perkembangan dunia konstruksi khususnya di Kabupaten Sorong maka peranan perusahaan konstruksi sangat penting dalam menunjang kesuksesan pembangunan dimana pada kenyataannya pembangunan merupakan prioritas utama masyarakat dalam menghadapi era globalisasi saat ini, sehingga memacu badan usaha atau perusahaan yang ada untuk terus-menerus melakukan perbaikan diri. Selain itu perkembangan perekonomian yang semakin pesat menyebabkan persaingan baik dalam bidang perdagangan maupun jasa semakin komplek. Persaingan ini membuat perusahaan harus melakukan strategi yang tepat sehingga dapat meningkatkan daya saing yang berkelanjutan. Untuk mencapai tujuan tersebut, Perusahaan Konstruksi harus mempunyai Kinerja yang baik. Kinerja suatu perusahaan dapat dijadikan sebagai suatu tolok ukur dari kemampuan suatu organisasi atau perusahaan dalam mencapai tujuannya. Pengukuran kinerja merupakan salah satu faktor yang sangat penting bagi organisasi atau perusahaan, karena pengukuran kinerja merupakan proses mengukur sejauh mana suatu perusahaan melakukan pekerjaan untuk mencapai tujuannya. Di Papua Barat sendiri dalam lingkup Dinas Pekerjaan Umum Kabupaten Sorong banyak terdapat perusahaan konstruksi baik berupa kontraktor maupun konsultan, dimana perusahaan yang satu dengan yang lainnya memiliki kinerja yang berbeda-beda satu sama lainnya. Berdasarkan latar belakang di atas, penulis mengambil judul penelitian:“Analisis Kinerja Perusahaan Konstruksi Di Kabupaten Sorong”

\section{Tujuan Penelitian}

Penelitian ini bertujuan untuk menganalisis kinerja perusahaan konstruksi (kontraktor) dalam lingkup Dinas Pekerjaan Umum Kabupaten Sorong dan untuk menganalisis faktor apa saja yang paling mempengaruhi kinerja perusahaan konstruksi (kontraktor) dalam menjalankan pekerjaan- pekerjaan yang ada dalam lingkup Dinas Pekerjaan Umum Kabupaten Sorong.

\section{STATE OF THE ART}

Adapun penelitian terdahulu yang terkait dengan penelitian ini adalah sebagai berikut :

1. Menurut Tumelap, J., Sumajouw, M. D., \& Waney, E. V (2014) menyebutkan berdasarkan hasil penelitian yang telah dilakukan diketahui bahwa faktor yang paling mempengaruhi kinerja adalah Faktor Internal disusul Faktor Situasi Pasar dan kemudian disusul Faktor Eksternal. Pada Faktor Internal disimpulkan bahwa Sistem Komunikasi antara Pimpinan dan Karyawan yang paling mempengaruhi kinerja. Pada Faktor Situasi Pasar disimpulkan bahwa Kemampuan Mencari dan Mendapatkan Proyek yang paling 
mempengaruhi kinerja. Pada Faktor Eksternal disimpulkan bahwa Kenaikan Harga Material dan Peralatan yang paling mempengaruhi kinerja.

2. Menurut Ichsan, M. (2015) menyebutkan berdasarkan hasil penelitian yang telah dilakukan diketahui bahwa terdapat tujuh belas variable kinerja yang telah memuaskan responden dan sembilan variable yang cukup memuaskan responden. Dalam perjalanan ke depannya diharapkan kontraktor mempertahankan ketujuh belas kinerja tersebut dan lebih meningkatkan lagi sembilan variable yang masih dalam kategori cukup puas.

3. Menurut Agsarini, I., \& Wiguna, I. P. (2015) menyebutkan berdasarkan hasil penelitian diperoleh variabel faktor kondisi proyek yaitu faktor ekonomi, faktor manajerial/organisasi, faktor sumber daya dan faktor eksternal, serta variabel kinerja proyek yaitu kinerja waktu, kinerja biaya dan kinerja mutu.

4. Menurut Maddeppungeng, A., Suryani, I., Setiawwati, D. N., \& Rudiyanto, A. (2017) menyebutkan berdasarkan hasil penelitian yang telah dilakukan menunjukkan bahwa pengaruh K3 terhadap kinerja perusahaan konstruksi pada hasil path diagram analisis adalah sebesar 0,594 atau 59,4\%. Serta pengaruh lingkungan terhadap kinerja adalah sebesar 0,243 atau sebesar 24,3\%. Sedangkan kolerasi lingkungan dan K3 terhadap kinerja sebesar 0,857 atau sebesar $85,7 \%$.

5. Menurut Supriana, T., \& Syarif, F. (2018) menyebutkan berdasarkan hasil penelitian yang telah dilakukan menunjukkan bahwasanya keseluruhan variabel yang diteliti yaitu : Persepsi Ketidakpastian Lingkungan, Kompetensi Manajer, Luasnya Cakupan Wilayah, Teknologi Informasi dan Keterbukaan Masyarakat dalam Menerima Pembangunan berpengaruh secara signifikan dan positif pada Kinerja Perusahaan BUMN Sektor Konstruksi yang terdapat di Kota Medan.

\section{METODE}

\section{Tahapan Penelitian}

Tahapan penelitian yang digunakan adalah sebagai berikut :

1. Melakukan studi pustaka terkait dengan judul penelitian dan pemahaman materi yang akan dipakai dalam penelitian.

2. Melakukan pengumpulan data primer dan data sekunder.

3. Menganalisis data yang telah terkumpul.

4. Melakukan uji validitas dan reliabilitas terhadap kuisioner.

Semua metode penulisan dan analisa dalam artikel ilmiah ini merujuk pada panduan penulisan tugas akhir Fakultas Teknik Universitas Muhammadiyah Sorong tahun 2014 (Pristianto, Amri, \& Rusdi, 2014).

\section{REFERENSI}

1. Pristianto, H., Amri, I., \& Rusdi, A. (2014, May 9). Pedoman Penulisan Tugas Akhir Fakultas Teknik Universitas Muhammadiyah Sorong 2014. http://doi.org/10.17605/OSF.IO/4VTJM. 
2. Tumelap, J., Sumajouw, M. D., \& Waney, E. V. (2014). Analisis Kinerja Perusahaan Jasa Pelaksana Konstruksi (Studi Kasus di Kabupaten Sarmi). Jurnal Ilmiah Media Engineering, 4(2).

3. Ichsan, M. (2015). Studi Kinerja Perusahaan Konstruksi Dalam Lingkup Dinas Pekerjaan Umum Kota Makassar. Universitas Hasanuddin, Makassar.

4. Agsarini, I., \& Wiguna, I. P. (2015). Pengaruh Faktor Kondisi Proyek terhadap Kinerja Proyek Konstruksi. Seminar Nasional Manajemen Teknologi XXII. Surabaya.

5. Maddeppungeng, A., Suryani, I., Setiawati, D. N., \& Rudiyanto, A. (2017). STUDI LINGKUNGAN KERJA DAN KESEHATAN KESELAMATAN KERJA TERHADAP KINERJA PERUSAHAAN KONSTRUKSI DALAM LINGKUP DINAS CIPTA KARYA, BINA MARGA, DAN SUMBERDAYA AIR PROVINSI BANTEN. Jurnal Fondasi, 6(1).

6. Supriana, T., \& Syarif, F. (2018). Faktor-Faktor yang Mempengaruhi Persepsi Manajer tentang Faktor yang Mempengaruhi Kinerja Perusahaan (Studi Empiris pada Perusahaan BUMN Sektor Konstruksi di Kota Medan). 